\title{
Fluorescence Spectroscopy Study on the Interaction of Acetal Cleavable Anionic Surfactants and Bovine Serum Albumin
}

\author{
Xin Zhang, Jianhong Bian, Wenjie Zhai, Jing Dong, Huihui Liang, and Zhao Zhang \\ School of Chemistry and Chemical Engineering, Shanxi University, Taiyuan, Shanxi 030006, China \\ Correspondence should be addressed to Zhao Zhang; z.zhang@sxu.edu.cn
}

Received 23 November 2013; Accepted 8 January 2014; Published 17 February 2014

Academic Editors: G. D’Errico, M. Mączka, and Y. Ueno

Copyright (C) 2014 Xin Zhang et al. This is an open access article distributed under the Creative Commons Attribution License, which permits unrestricted use, distribution, and reproduction in any medium, provided the original work is properly cited.

The interactions between bovine serum albumin (BSA) and two cleavable anionic surfactants, sodium 3-[(2-nonyl-1,3-dioxolan4-yl)methoxy]propane-1-sulfonate (SNPS) and sodium 3,3'-(2-nonyl-1,3-dioxane-5,5-diyl)bis(methylene)bis(oxy)dipropane-1sulfonate (SNDPS), have been studied by means of fluorescence spectroscopy and thermodynamic analysis. The fluorescence of BSA is quenched via a static quenching mechanism with the addition of the surfactants. The binding constants of the surfactants and proteins have been measured, with $K_{A}(\mathrm{SNPS})=8.71 \times 10^{4} \mathrm{M}^{-1}$ and $K_{A}(\mathrm{SNDPS})=7.08 \times 10^{4} \mathrm{M}^{-1}$, respectively. The interaction between surfactants and BSA is mainly of hydrophobic nature, based on the number of binding $\operatorname{sites,~} n[n$ (SNPS) $=$ $1.57, n($ SNDPS $)=1.47$, and the thermodynamic relationship. These results suggest that SNPS and SNDPS could be effective protein denaturants for protein separation and analysis.

\section{Introduction}

Protein is an integral part of life in organisms and can bind a wide variety of ligands such as surfactants, drugs, toxicants, and heavy metal ions [1-6]. Studies on the interactions between surfactants and proteins would be beneficial for understanding the occurence of surfactants acting as solubilizing or denaturing agents for proteins $[7,8]$. For example, serum albumins are the most abundant proteins in blood plasma and are the major soluble protein in the circulatory system [9]. They play an important role in the transport of endogenous and exogenous ligands in blood. Studying the interaction between surfactants and serum albumins would have a significant impact on the development of protein separation and analysis methods as well as our understanding of the metabolism of endogenous and exogenous ligands [10].

Traditionally, the single-chain surfactants, like cetyltrimethyl ammonium bromide (CTAB) and sodium dodecyl sulfate (SDS), have been widely used in proteomic research, such as protein separation and analysis [11-14]. However, the applications are sometimes complicated due to the formation of foams and emulsions. This also encourages the interest in researching the synthesis of simple and practical surfactants and developing desirable methods in proteomic research. Recently, protein-gemini surfactants interactions have been developed because these surfactants have a low critical micelle concentration (CMC), a low Krafft temperature, a strong hydrophobic microdomain, and a superior viscous behavior in comparison to the conventional single-chain surfactants [15-18]. However, the complex synthesis and purification procedures associated with these surfactants often lead to expensive consumption which limits the application of gemini surfactants in proteomic research. Other surfactants-such as quaternary ammonium salts containing pyridine ring [19] and nonionic surfactant polysorbate 20 (Tween-20) [20]-have also been explored. But these surfactants are hard to degrade and separate, and they usually form foams and emulsions in solution, making them not so "green" alternatives in proteomic analysis, especially when separating proteins. The increase in environmental awareness and economic concerns have led to the further consideration of synthesizing highly efficient and green surfactants, which can be used in protein research.

Cleavable surfactants are amphiphiles in which a weak linkage has been deliberately inserted between the hydrophobic tail and the polar headgroup [21,22]. These surfactants 
may degrade by chemical means including acid and alkali [23-28], heat [29], light [30], and ozone [31]. Great attention has been drawn to probing the acid- and alkali-labile surfactants due to their superior controllability and their environmentally friendlier and potential industrial application [22]. Acid- and alkali-labile surfactants are very stable under a given set of conditions, usually under neutral $\mathrm{pH}$, but are cleaved when the $\mathrm{pH}$ changes. The decomposition products are usually a series of small molecules, which could avoid the formation of foams and emulsions and eliminate the impact of surfactant with further separation and analysis. Applied to protein research, cleavable surfactants can be degraded after reaction with proteins and the decomposition products do not need to be removed because they would not interfere with postanalysis methods such as HPLC, MALDIMS, and LC/MS or protein separation methods such as twodimensional gel electrophoresis (2-DE) and chromatography. Therefore, cleavable surfactants would simplify the protein analysis and separation procedure in comparison to traditionally undecomposable surfactants.

Herein, we report the denaturation research of bovine serum albumin (BSA) which is a common serum albumin protein and has homology structure with human serum albumin (HSA), by employing acetal cleavable anionic surfactants SNPS and SNDPS (Figure 1) using fluorescence spectroscopy method. This study would give new alternatives in the field of proteomic research.

\section{Experimental}

2.1. Instruments and Materials. Bovine serum albumin (BSA) was purchased from Tianjin Biochemical Products Company. Phosphate buffered saline (PBS, $\mathrm{pH}$ 7.2) was purchased from Gibco Invitrogen. Glycerol, pentaerythrite, decanal, paratoluenesulfonic acid $(\mathrm{p}-\mathrm{TsOH})$, sodium hydride $\mathrm{NaH}$, and 1,3-propyl sultone were purchased from Sigma-Aldrich. Other reagents and all organic solvents were purchased from Tianjin Chemical Co. All chemical reagents were of analytical grade and used as received. Organic solvents were dried according to the standard procedures before using. All reactions were run under magnetically stirred and were monitored by thin-layer chromatography (TLC). Flash chromatography (FC) was performed using silica gel 60 (200-300 mesh). All the normalized fluorescence spectra were recorded on a LS-55 Spectrofluorometer (Perkin-Elmer Company) equipped with a pulse xenon lamp. IR spectra were recorded on a Shimadzu 8400-S. Proton nuclear magnetic resonance $\left({ }^{1} \mathrm{H} \mathrm{NMR}\right)$ spectra were recorded on a Brucker DRX $300 \mathrm{MHz}$ NMR spectrometer. The critical micellar concentrations (CMC) of SNPS and SNDPS were determined at $20^{\circ} \mathrm{C}$ using a DDSJ-308A conductivity meter purchased from Shanghai Precision \& Scientific Instrument Co., LTD.

2.2. Synthesis of SNPS and SNDPS. The anionic surfactants (SNPS and SNDPS) were synthesized using the procedures (Scheme 1) defined in the literature [24, 25].

2.2.1. Synthesis of Compound 1. Glycerol (4.42 g, $48 \mathrm{mmol})$ and $40 \mathrm{~mL}$ benzene were placed in a $100 \mathrm{~mL}$, three-necked flask equipped with an electromagnetic stirrer and an oilwater separator combined with condenser and stirred at $60^{\circ} \mathrm{C}$ for 20 mins under $\mathrm{N}_{2}$ protect. Then decanal $(7.02 \mathrm{~g}$, $45 \mathrm{mmol}$ ) and p-TsOH (0.5 g, $2.5 \mathrm{mmol})$ were carefully added. The mixture was stirred at reflux temperature for $24 \mathrm{~h}$. After cooling, the mixture was washed with $2 \% \mathrm{NaHCO}_{3}$ solution $(100 \mathrm{~mL})$ three times and water $(100 \mathrm{~mL})$ one time. The organic phase was dried with $\mathrm{MgSO}_{4}$ and concentrated and purified by flash chromatography ( $n$-hexane EtOAc $=1: 1$ ) that afforded $7.80 \mathrm{~g}$ product as a white solid. Yield: $75.3 \%$. mp 60-62 ${ }^{\circ} \mathrm{C}$; IR (KBr, $\left.v / \mathrm{cm}^{-1}\right): 3411,2924,2860,1456,1407,1180$, 1107, 1074, 929, 734, and 699; ${ }^{1} \mathrm{H} \mathrm{NMR}\left(300 \mathrm{MHz}, \mathrm{CDCl}_{3}\right): \delta$ $0.87(\mathrm{t}, 3 \mathrm{H}), 1.33(\mathrm{~m}, 14 \mathrm{H}), 1.59(\mathrm{~m}, 2 \mathrm{H}), 2.03(\mathrm{~s}, 1 \mathrm{H}), 3.60$ $(\mathrm{d}, 2 \mathrm{H}), 3.84(\mathrm{~m}, 2 \mathrm{H}), 4.16(\mathrm{~m}, 1 \mathrm{H})$, and $4.89(\mathrm{t}, 1 \mathrm{H})$.

2.2.2. Synthesis of Compound 2. Pentaerythrite (6.50 g, $48 \mathrm{mmol}$ ) and $40 \mathrm{~mL}$ DMF were placed in a $100 \mathrm{~mL}$, threenecked flask equipped with an electromagnetic stirrer and condenser and stirred at $60^{\circ} \mathrm{C}$ for 20 mins under $\mathrm{N}_{2}$ protect. Then decanal $(7.02 \mathrm{~g}, 45 \mathrm{mmol})$ and $\mathrm{p}-\mathrm{TsOH}(0.3 \mathrm{~g}$, $1.5 \mathrm{mmol}$ ) were carefully added. The mixture was stirred at $80^{\circ} \mathrm{C}$ for $24 \mathrm{~h}$. After cooling, the mixture was concentrated by reduced pressure distillation. The crude product was dissolved in $60 \mathrm{~mL}$ EtOAc; the solution was then filtered to remove insoluble substances. The filtrate was washed with $2 \%$ $\mathrm{NaHCO}_{3}$ solution $(100 \mathrm{~mL})$ three times and water $(100 \mathrm{~mL})$ one time. The organic phase was dried with $\mathrm{MgSO}_{4}$ and concentrated and purified by recrystallization from $n$-hexace to give product $4.22 \mathrm{~g}$ as a white solid. Yield: $34.2 \%$. $\mathrm{mp} 89$ $90^{\circ} \mathrm{C}$; IR (KBr, $\left.v / \mathrm{cm}^{-1}\right)$ : 3256, 2953, 2920, 2851, 1470, 1404, 1157, 1117, 1057, 999, 935, 721, and 690; ${ }^{1} \mathrm{H}$ NMR $(300 \mathrm{MHz}$, $\left.\mathrm{CDCl}_{3}\right): \delta 0.88(\mathrm{t}, 3 \mathrm{H}), 1.29-1.36(\mathrm{~m}, 14 \mathrm{H}), 1.60(\mathrm{~m}, 2 \mathrm{H}), 2.01$ $(\mathrm{s}, 2 \mathrm{H}), 3.50(\mathrm{~m}, 4 \mathrm{H}), 4.00(\mathrm{q}, 2 \mathrm{H}), 4.06(\mathrm{q}, 2 \mathrm{H})$, and $4.43(\mathrm{t}$, $1 \mathrm{H})$.

2.2.3. General Procedures for Synthesis of SNPS and SNDPS. Compounds 1 or 2 , benzene, and $\mathrm{NaH}$ were placed in a $100 \mathrm{~mL}$, three-necked flask equipped with an electromagnetic stirrer, and stirred at room temperature for $12 \mathrm{~h}$ under $\mathrm{N}_{2}$ protect. Then 1,3-propyl sultone was added dropwise. The mixture was stirred at reflux temperature for $24 \mathrm{~h}$. After cooling, the mixture was concentrated to obtain the crude product. The crude product was purified by recrystallization from mixture solvent of water and ethanol to give product.

(1) Synthesis of SNPS. Application of above procedure (recrystallization from mixture solvent: water/ethanol $=4 / 1$ ) to compound 1 (7.80 g, $33.9 \mathrm{mmol}), \mathrm{NaH}(1.00 \mathrm{~g}, 41.5 \mathrm{mmol})$, benzene $(60 \mathrm{~mL})$, and 1,3-propyl sultone $(5.00 \mathrm{~g}, 41.0 \mathrm{mmol})$ afforded compound SNPS (10.12 g, 79.7\%) as a white solid. IR $\left(\mathrm{KBr}, \nu / \mathrm{cm}^{-1}\right): 2931,2874,1445,1418,1202,1111,1063,924,797$, 735, 619, and 532; ${ }^{1} \mathrm{H}$ NMR $\left(300 \mathrm{MHz}, \mathrm{D}_{2} \mathrm{O}\right): \delta 0.89(\mathrm{t}, 3 \mathrm{H})$, 0.99-1.04 (m, $14 \mathrm{H}), 1.45$ (m, $2 \mathrm{H}), 2.01(\mathrm{~m}, 2 \mathrm{H}), 3.37-3.63$ (m, $6 \mathrm{H}), 3.98(\mathrm{~m}, 2 \mathrm{H}), 4.20(\mathrm{~m}, 1 \mathrm{H})$, and $4.69(\mathrm{t}, 1 \mathrm{H})$.

(2) Synthesis of SNDPS. Application of above procedure (recrystallization from mixture solvent: water/ethanol $=1 / 1$ ) to compound 2 (4.22 g, $15.4 \mathrm{mmol}), \mathrm{NaH}$ (1.00 g, $41.5 \mathrm{mmol}$ ), 


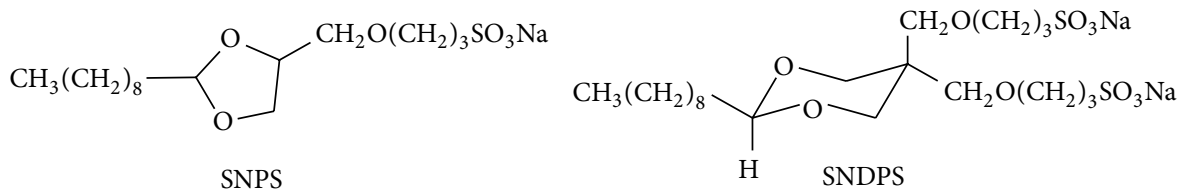

FIGURE 1: The structures of SNPS and SNDPS.

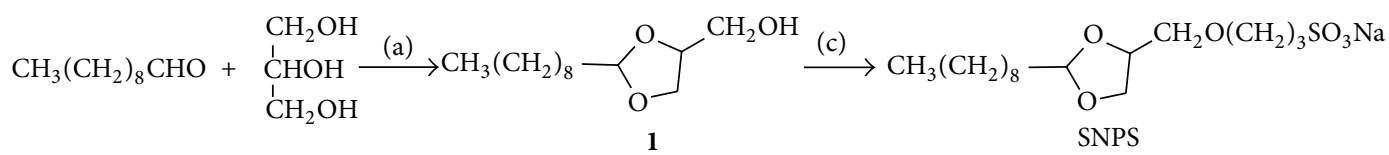

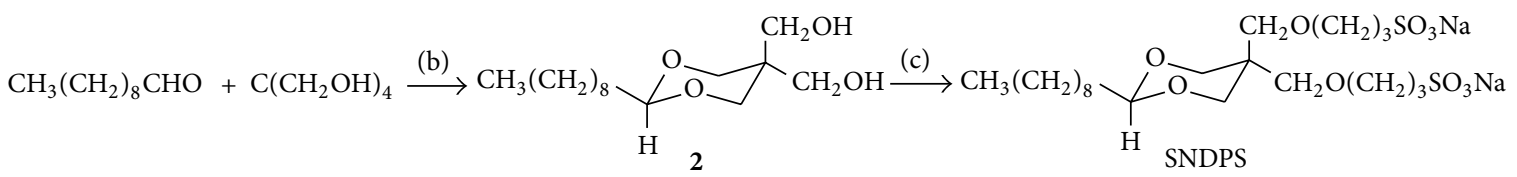

Scheme 1: Syntheses of anionic surfactants SNPS and SNDPS. (a) p-TsOH, benzene, reflux; (b) p-TsOH, DMF, 90-100 C; (c) NaH, benzene; 1,3-propyl sultone, reflux.

benzene $(35 \mathrm{~mL})$, and 1,3-propyl sultone $(5.00 \mathrm{~g}, 41.0 \mathrm{mmol})$ afforded compound SNDPS (6.52 g, 75.4\%) as a white solid. IR $\left(\mathrm{KBr}, v / \mathrm{cm}^{-1}\right): 2925,2855,1429,1407,1375,1180,1107,1061$, 883, 796, 617, 532; ${ }^{1} \mathrm{H}$ NMR $\left(300 \mathrm{MHz}, \mathrm{D}_{2} \mathrm{O}\right): \delta 0.78(\mathrm{t}, 3 \mathrm{H})$, 1.29-1.37 (m, $14 \mathrm{H}), 1.62$ (m, $2 \mathrm{H}), 1.98-2.08$ (m, $4 \mathrm{H}), 2.94-$ $3.20(\mathrm{~m}, 4 \mathrm{H}), 3.32(\mathrm{~s}, 2 \mathrm{H}), 3.57(\mathrm{t}, 2 \mathrm{H}), 3.67(\mathrm{t}, 2 \mathrm{H}), 3.71(\mathrm{~s}$, $2 \mathrm{H}), 3.77(\mathrm{~d}, 2 \mathrm{H}), 3.96(\mathrm{~d}, 2 \mathrm{H})$, and $4.68(\mathrm{t}, 1 \mathrm{H})$.

2.3. The Critical Micellar Concentrations of Surfactants. The conductivity $\sigma$ of different concentrations of surfactants water solution, ranging from $2 \times 10^{-5} \mathrm{~mol} / \mathrm{L}$ to $2 \times 10^{-2} \mathrm{~mol} / \mathrm{L}$, was measured by conductivity meter. From the plot of the conductivity $\sigma$ with respect to the surfactants' concentrations, the CMC was determined. Results showed the CMC of SNPS and SNDPS that were $2.4 \times 10^{-3} \mathrm{M}$ and $7.0 \times 10^{-3} \mathrm{M}$, respectively, at $20^{\circ} \mathrm{C}$.

2.4. Hydrolysis of Surfactants. Hydrolysis studies of cleavable surfactants were performed in an acidic environment (Scheme 2). Briefly, the surfactant sample $(0.1 \mathrm{mmol})$ was placed in different concentrations of $\mathrm{HCl}$ solution $(100 \mathrm{~mL})$, ranging from $1 \times 10^{-4} \mathrm{~mol} / \mathrm{L}$ to $1 \mathrm{~mol} / \mathrm{L}$; then the mixture was stirred at $40^{\circ} \mathrm{C}$. After a time, the solution was neutralized by adding $0.1 \mathrm{~mol} / \mathrm{L} \mathrm{NaHCO}_{3}$ solution. Then the mixture was extracted three times by using $25 \mathrm{~mL}$ ether. The combined organic phase was dried with $\mathrm{MgSO}_{4}$, concentrated, and then checked by NMR to make sure that the decomposition yields. The results showed that SNPS and SNDPS were decomposed completely when they were placed in $0.2 \mathrm{~mol} / \mathrm{L} \mathrm{HCl}$ at $40^{\circ} \mathrm{C}$ for $10 \mathrm{~h}$ and $16 \mathrm{~h}$, respectively.

2.5. Fluorescence Spectra of Denatured BSA. Typically, $0.5 \mathrm{~mL}$ of the $1 \times 10^{-4} \mathrm{~mol} / \mathrm{L}$ BSA solution and an appropriate amount of the cleavable surfactants were transferred into a $5 \mathrm{~mL}$ volumetric flask, and the mixed solution was buffered with PBS buffer ( $\mathrm{pH}$ 7.2). The system was diluted to $5 \mathrm{~mL}$ of final volume with distilled water. After sitting aside for $30 \mathrm{~min}$ at $20^{\circ} \mathrm{C}$, the solution was transferred into a $1 \mathrm{~cm}$ capped quartz cell. Fluorescence spectra were acquired at an excitation wavelength of $280 \mathrm{~nm}$.

\section{Results and Discussion}

As it can be seen from Figures 2 and 3, the emission peak of BSA appears at $350 \mathrm{~nm}$, and its intensity underwent a gradual decrease accompanied by a blue shift of the emission spectra with the addition of the surfactants (curves 2-9 in both figures). This fluorescence quenching of BSA is probably due to the exposure of the tryptophan residues during the denaturation process. It could be either the static and/or the dynamic quenching [32]. Dynamic quenching, involving either energy transfer or electron transfer, does not alter protein structure and physiological activities, while static quenching may change secondary structures and physiological activities through the formation of a nonfluorescent fluorophore-quencher complex.

To investigate the nature of the quenching process, the fluorescence intensity in the presence of different concentrations of the quenchers was analyzed. Assuming that the quenching is dynamic, the fluorescence intensity would follow the Stern-Volmer equation (1):

$$
\frac{F_{0}}{F}=1+K_{\mathrm{sv}}[Q]=1+\tau_{0} K_{q}[Q] \text {, }
$$

where $F_{0}$ is the fluorescence intensity in the absence of a quencher; $F$ is the fluorescence intensity in the presence of a quencher; $[Q]$ is the quencher concentration; $\tau_{0}$ is the lifetime of the fluorophore in the absence of the quencher; and $K_{\mathrm{sv}}$ is referred to as the Stern-Volmer constant, which can be determined from the slope of the Stern-Volmer plot.

For the surfactant SNPS (Figure 4), $K_{\mathrm{sv}}=1.76 \times 10^{3} \mathrm{M}^{-1}$ when [SNPS] $<1.2 \times 10^{-3} \mathrm{M}$ and $K_{\mathrm{sv}}=4.66 \times 10^{3} \mathrm{M}^{-1}$ when [SNPS] $>1.2 \times 10^{-3} \mathrm{M}$. Generally, the average fluorescence lifetime of biological macromolecule is $10^{-8} \mathrm{~s}$ [33]. Therefore, 


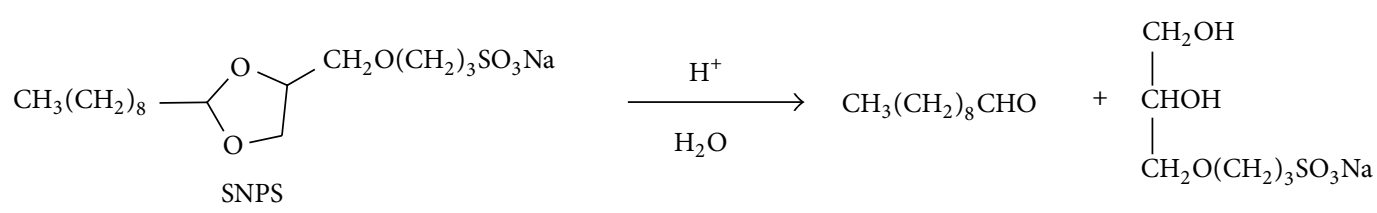

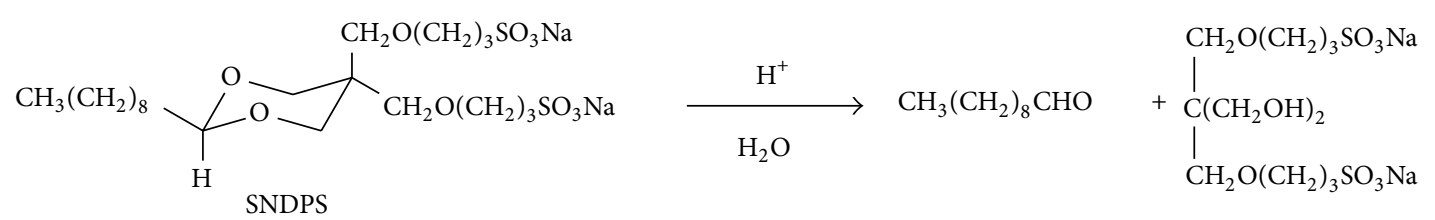

SCHEME 2: Hydrolysis of anionic surfactants SNPS and SNDPS.

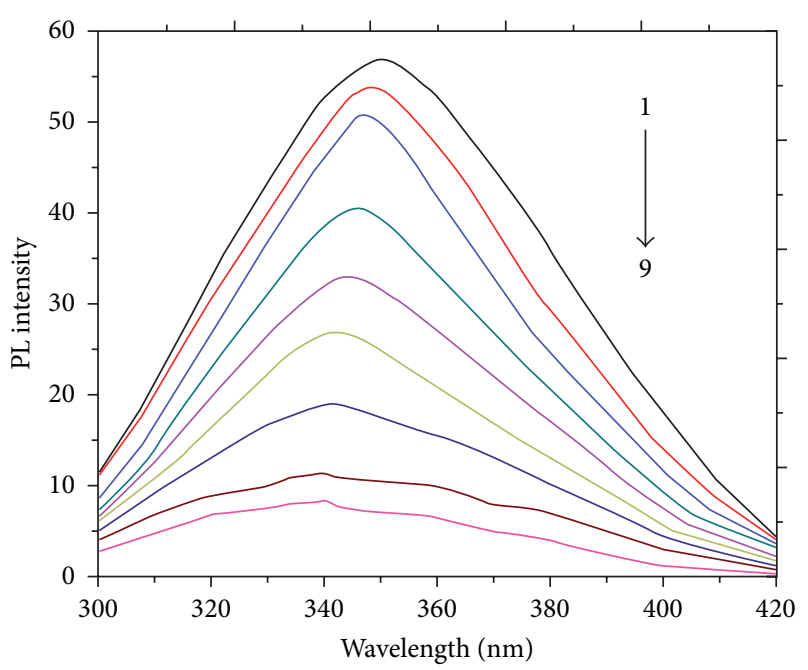

Figure 2: Fluorescence (emission) spectra of BSA. Curves 1 to 9 are for $[\mathrm{SNPS}]=0,0.1,0.2,0.4,0.6,0.8,1.2,1.6$, and $2.0 \times 10^{-3} \mathrm{~mol} \cdot \mathrm{L}^{-1}$, respectively.

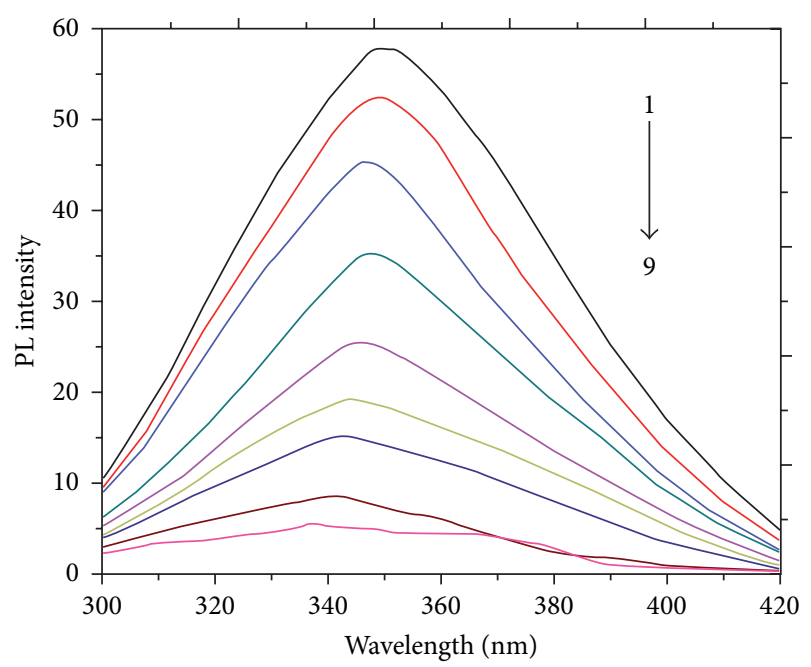

FIgURE 3: Fluorescence (emission) spectra of BSA. Curves 1 to 9 are for $[$ SNDPS $]=0,0.1,0.2,0.4,0.6,0.8,1.2,1.6$, and $2.0 \times 10^{-3} \mathrm{~mol} \cdot \mathrm{L}^{-1}$, respectively. the rate constant $\left(K_{q}\right)$ should be $1.76 \times 10^{11} \mathrm{M}^{-1} \mathrm{~s}^{-1}, 4.66 \times$ $10^{11} \mathrm{M}^{-1} \mathrm{~s}^{-1}$, respectively, according to (2). Similarly, for SNDPS (Figure 5), $K_{\mathrm{sv}}=2.61 \times 10^{3} \mathrm{M}^{-1}$ when [SNDPS] $<$ $1.2 \times 10^{-3} \mathrm{M}$ and $K_{\mathrm{sv}}=8.39 \times 10^{3} \mathrm{M}^{-1}$ when [SNDPS] $>1.2 \times$ $10^{-3} \mathrm{M}$. The respective value of $K_{q}$ is $2.61 \times 10^{11} \mathrm{M}^{-1} \mathrm{~s}^{-1}$ and $8.39 \times 10^{11} \mathrm{M}^{-1} \mathrm{~s}^{-1}$ for SNDPS. It is well known that the largest rate constant of diffusive collision in the quenching process is $2.0 \times 10^{10} \mathrm{M}^{-1} \mathrm{~s}^{-1}$ [34]. The values of $K_{q}$ of the two surfactants (Table 1) for BSA were both larger than this number. It can be concluded that the quenching is most likely a static process rather than a dynamic one, and a BSA-surfactant complex is probably formed during the interaction.

For the static fluorescence quenching process, the fluorescence intensity would follow the Lineweaver-Burk equation (2),

$$
\log \left[\frac{F_{0}-F}{F}\right]=\log K_{A}+n \log [Q] .
$$

The values of $K_{A}$ and $n$ could be obtained from the $\log \left[\left(F_{0}-F\right) / F\right] \sim \log [Q]$ plot. Using this analysis, the data of $K_{A}$ and $n$ for both SNPS and SNDPS were listed in Table 1.

In the three-dimensional structure of BSA, there are three domains and each domain consists of two subdomains. Almost all the hydrophobic residues were found inside the hydrophobic cylindrical troughs in these domains [35]. For the formation of a BSA-surfactant complex, the following thermodynamic equation (3) would apply:

$$
\Delta G=\Delta H-T \Delta S=-\mathrm{RT} \ln \left(K_{A}\right) .
$$

The temperature fluctuation during the interaction of surfactants with BSA was very small (within $293.0 \pm 0.1 \mathrm{~K}$ ) and the change in enthalpy was assumed to be negligible $(\Delta H \sim 0)$. The change in Gibbs energy $(\Delta G)$ and entropy $(\Delta S)$ for the interaction between surfactants and BSA were listed in Table 1.

As shown in Table 1 , both the binding constant $K_{A}(8.71 \times$ $10^{4} \mathrm{M}^{-1}$ ) and the binding site number $n$ (1.57) of SNPS are slightly greater than those of SNDPS $\left(K_{A}=7.08 \times 10^{4} \mathrm{M}^{-1}\right)$ and $(n=1.47)$. The change in Gibbs energy $(\Delta G)$ of SNPS is more negative than that of SNDPS. This is probably due to the smaller size of SNPS with only one anionic alkylsulfonic 
TABLE 1: Values of $K_{\mathrm{sv}}, K_{q}, K_{A}, n$, and the thermodynamic data for the interaction of surfactants with BSA.

\begin{tabular}{lcccccc}
\hline Surfactant & $K_{\mathrm{sv}}\left(10^{3} \mathrm{M}^{-1}\right)$ & $K_{q}\left(10^{11} \mathrm{M}^{-1} \mathrm{~s}^{-1}\right)$ & $K_{A}\left(10^{4} \mathrm{M}^{-1}\right)$ & $n$ & $\Delta G\left(\mathrm{~J} \mathrm{~mol}^{-1}\right)$ & $\Delta S\left(\mathrm{~J} \mathrm{~mol}^{-1} \mathrm{~K}^{-1}\right)$ \\
\hline SNPS & $1.76 ; 4.66$ & $1.76 ; 4.66$ & 8.71 & 1.57 & -3891.2 & 13.28 \\
SNDPS & $2.61 ; 8.39$ & $2.61 ; 8.39$ & 7.08 & 1.47 & -3846.4 & 13.13 \\
\hline
\end{tabular}

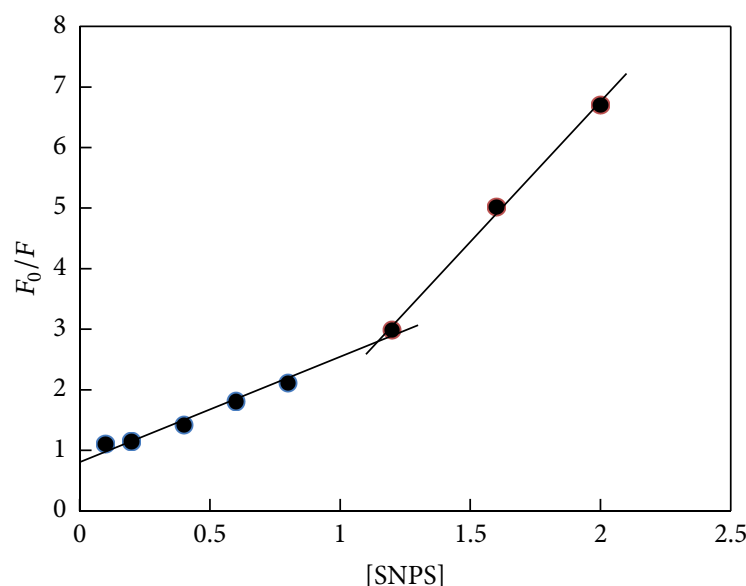

FIGURE 4: Stern-Volmer plot for the fluorescence quenching of BSA by SNPS.

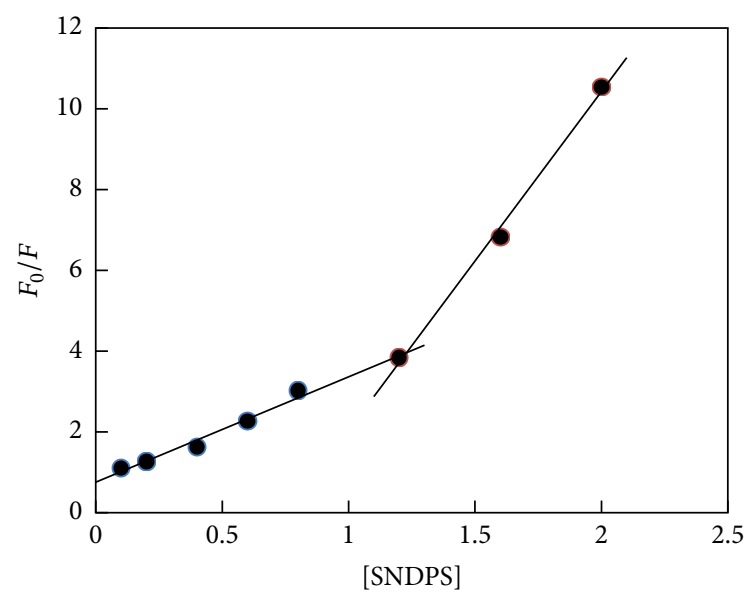

FIGURE 5: Stern-Volmer plot for the fluorescence quenching of BSA by SNDPS.

group. It is easier for SNPS to enter the hydrophobic cavities of BSA than SNDPS. Based on these data, we postulate that the interaction of surfactants with BSA was probably driven by the hydrophobic interaction.

\section{Conclusions}

In summary, the fluorescence quenching of SNPS and SNDPS to BSA was found to follow the Stern-Volmer equation. The binding constant $K_{A}$, the binding site number $n$, and thermodynamic data indicate that it is easier for BSA to bind to SNPS with one anionic alkylsulfonic group than to bind to SNDPS possessing two sulfonic groups. The binding between the surfactants and BSA was believed to arise from the interaction of the surfactant with the hydrophobic cavity of BSA. BSA can be completely denaturalized by less cleavable surfactants. These results should be useful for the development of new analysis or separation methods in proteomic research. Studies on further applications of SNPS and SNDPS as cleavable anionic surfactants in the separation and analysis of proteins are currently underway in our laboratory.

\section{Conflict of Interests}

The authors declare that there is no conflict of interests regarding the publication of this paper.

\section{Acknowledgments}

The authors are exceedingly grateful for support received from Shanxi Scholarship Council of China (no. 200817) and The Science and Technology Project for the Higher Educational Institutes of Shanxi Province of China (no. 20080001).

\section{References}

[1] Y.-Q. Xu, A. Malkovskiy, and Y. Pang, "A graphene bindingpromoted fluorescence enhancement for bovine serum albumin recognition," Chemical Communications, vol. 47, no. 23, pp. 6662-6664, 2011.

[2] H. Xu, Q.-W. Liu, Y. Zuo, Y. Bi, and S.-L. Gao, "Spectroscopic studies on the interaction of vitamin $\mathrm{C}$ with bovine serum albumin," Journal of Solution Chemistry, vol. 38, no. 1, pp. 1525, 2009.

[3] U. S. Mote, S. L. Bhattar, S. R. Patil, and G. B. Kolekar, "Interaction between felodipine and bovine serum albumin: fluorescence quenching study," Luminescence, vol. 25, no. 1, pp. $1-8,2010$.

[4] Y. Liu, M.-M. Chen, G.-L. Bian, J.-F. Liu, and L. Song, "Spectroscopic investigation of the interaction of the toxicant, 2naphthylamine, with bovine serum albumin," Journal of Biochemical and Molecular Toxicology, vol. 25, no. 6, pp. 362-368, 2011.

[5] B.-S. Liu, C. Yang, J. Wang, C.-L. Xue, and Y.-K. Lv, "Investigation on the competition interaction of synthetic food colorants and ciprofloxacin hydrochloride with bovine serum albumin by fluorescence spectroscopy," Journal of Thermodynamics, vol. 2011, Article ID 137531, 7 pages, 2011.

[6] D. Crespy, K. Landfester, U. S. Schubert, and A. Schiller, "Potential photoactivated metallopharmaceuticals: from active molecules to supported drugs," Chemical Communications, vol. 46, no. 36, pp. 6651-6662, 2010.

[7] M. N. Jones, "Surfactant interactions with biomembranes and proteins," Chemical Society Reviews, vol. 21, no. 2, pp. 127-136, 1992. 
[8] J. Liu, J. Tian, X. Tian, Z. Hu, and X. Chen, "Interaction of isofraxidin with human serum albumin," Bioorganic \& Medicinal Chemistry, vol. 12, no. 2, pp. 469-474, 2004.

[9] D. C. Carter and J. X. Ho, "Structure of serum albumin," Advances in Protein Chemistry, vol. 45, pp. 153-203, 1994.

[10] Y.-J. Li, X.-Y. Wang, and Y.-L. Wang, "Comparative studies on interactions of bovine serum albumin with cationic gemini and single-chain surfactants," The Journal of Physical Chemistry B, vol. 110, no. 16, pp. 8499-8505, 2006.

[11] N. Gulla, S. Chodankarb, V. K. Aswalb, P. Senc, R. H. Khanc, and K. Din, "Spectroscopic studies on the interaction of cationic surfactants with bovine serum albumin," Colloids and Surfaces $B$, vol. 69, no. 1, pp. 122-128, 2009.

[12] S. S. Madaeni and E. Rostami, "Spectroscopic investigation of the interaction of BSA with cationic surfactants," Chemical Engineering and Technology, vol. 31, no. 9, pp. 1265-1271, 2008.

[13] A. Sharma, P. K. Agarwal, and S. Deep, "Characterization of different conformations of bovine serum albumin and their propensity to aggregate in the presence of N-cetyl-N,N,Ntrimethyl ammonium bromide," Journal of Colloid and Interface Science, vol. 343, no. 2, pp. 454-462, 2010.

[14] J. M. Ruso, N. Deo, and P. Somasundaran, "Complexation between dodecyl sulfate surfactant and zein protein in solution," Langmuir, vol. 20, no. 21, pp. 8988-8991, 2004.

[15] Y. Wang, E. F. Marques, and C. M. Pereira, "Monolayers of gemini surfactants and their catanionic mixtures with sodium dodecyl sulfate at the air-water interface: chain length and composition effects," Thin Solid Films, vol. 516, no. 21, pp. 74587466, 2008.

[16] N. Gull, P. Sen, R. H. Khan, and D. Kabirud, "Interaction of bovine (BSA), rabbit (RSA), and porcine (PSA) serum albumins with cationic single-chain/gemini surfactants: a comparative study," Langmuir, vol. 25, no. 19, pp. 11686-11691, 2009.

[17] H. Tan and H. Xiao, "Synthesis and antimicrobial characterization of novel l-lysine gemini surfactants pended with reactive groups," Tetrahedron Letters, vol. 49, no. 11, pp. 1759-1761, 2008.

[18] X. Huang, Y. Han, Y. Wang, M. Cao, and Y. Wang, "Aggregation properties of cationic gemini surfactants with dihydroxyethylamino headgroups in aqueous solution," Colloids and Surfaces A, vol. 325, no. 1-2, pp. 26-32, 2008.

[19] S. Tu, X.-H. Jiang, L.-M. Zhou et al., "Study of the interaction of gemini surfactant NAE12-4-12 with bovine serum albumin," Journal of Luminescence, vol. 132, no. 2, pp. 381-385, 2012.

[20] J. Liu, G.-Y. Xu, D. Wu, and L. Yu, "Spectroscopic study on the interaction between bovine serum albumin and tween-20," Journal of Dispersion Science and Technology, vol. 27, no. 6, pp. 835-838, 2006.

[21] D. Shukla and V. K. Tyagi, "Development of cleavable surfactants," Tenside, Surfactants, Detergents, vol. 47, no. 1, pp. 7-12, 2010.

[22] A. Tehrani-Bagha and K. Holmberg, "Cleavable surfactants," Current Opinion in Colloid and Interface Science, vol. 12, no. 2, pp. 81-91, 2007.

[23] S. Yamamura, M. Nakamura, K. Kasai, H. Sato, and T. TakedaYukagaku, "Synthesis and properties of destructible anionic surfactants with a 1,3-dioxolane ring and their use as emulsifier for emulsion polymerization," Journal of Japan Oil Chemists' Society, vol. 40, pp. 1002-1006, 1991.

[24] G.-W. Wang, X.-Y. Yuan, Y.-C. Liu, X.-G. Lei, and Q.-X. Guo, "Synthesis and characterization of cleavable cationic surfactants with a 1,3-dioxane ring," Journal of the American Oil Chemists' Society, vol. 72, no. 1, pp. 83-87, 1995.
[25] A. Piasecki and A. Mayhew, "Synthesis and surface properties of chemodegradable anionic surfactants: diastereomeric (2-nalkyl-1,3-dioxan-5-yl) sulfates with monovalent counter-ions," Journal of Surfactants and Detergents, vol. 3, no. 1, pp. 59-65, 2000.

[26] A. Piasecki, B. Burczyk, and P. Ruchała, "Synthesis and surface properties of chemodegradable anionic surfactants: sodium carboxylates 1 of cis-1,3-dioxane derivatives," Journal of Surfactants and Detergents, vol. 1, no. 1, pp. 29-35, 1998.

[27] D. A. Jaeger and S. G. G. Russell, "Second generation doublechain cleavable surfactants," Tetrahedron Letters, vol. 34, no. 44, pp. 6985-6988, 1993.

[28] D. A. Jaeger and Y. M. Sayed, "Synthesis and characterization of single-chain second generation cleavable surfactants," Journal of Organic Chemistry, vol. 58, no. 9, pp. 2619-2627, 1993.

[29] T. M. Long, B. A. Simmons, J. R. McElhanon et al., "Metathesis depolymerization for removable surfactant templates," Langmuir, vol. 21, no. 20, pp. 9365-9373, 2005.

[30] P.-E. Hellberg, K. Bergström, and K. Holmberg, "Cleavable surfactants," Journal of Surfactants and Detergents, vol. 3, no. 1, pp. 81-91, 2000.

[31] A. Masuyama, C. Endo, S.-Y. Takeda, and M. Nojima, "Ozonecleavable gemini surfactants, a new candidate for an environmentally friendly surfactant," Chemical Communications, no. 18, pp. 2023-2024, 1998.

[32] J.-B. Le Pecq and C. Paoletti, "A new fluorometric method for RNA and DNA determination," Analytical Biochemistry, vol. 17, no. 1, pp. 100-107, 1966.

[33] J. R. Lakowicz and G. Weber, "Quenching of fluorescence by oxygen. A probe for structural fluctuations in macromolecules," Biochemistry, vol. 12, no. 21, pp. 4161-4170, 1973.

[34] W. R. Ware, "Oxygen quenching of fluorescence in solution: an experimental study of the diffusion process," Journal of Physical Chemistry, vol. 66, no. 3, pp. 455-458, 1962.

[35] U. Kragh-Hansen, "Molecular aspects of ligand binding to serum albumin," Pharmacological Reviews, vol. 33, no. 1, pp. 17$53,1981$. 

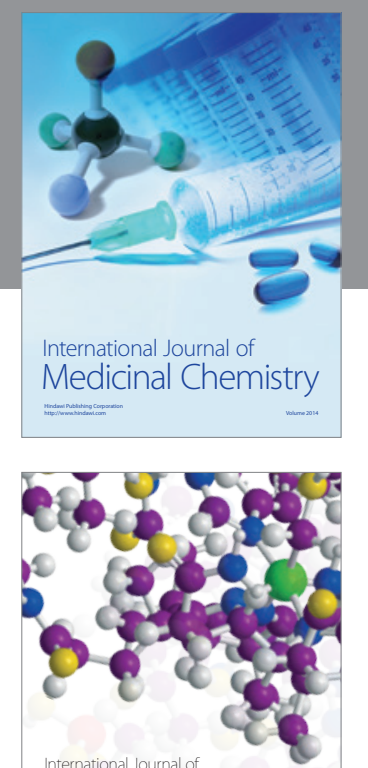

\section{Carbohydrate} Chemistry

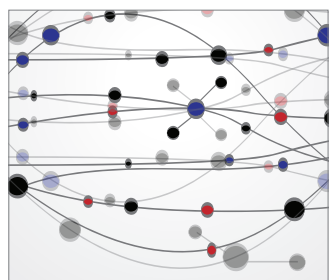

The Scientific World Journal
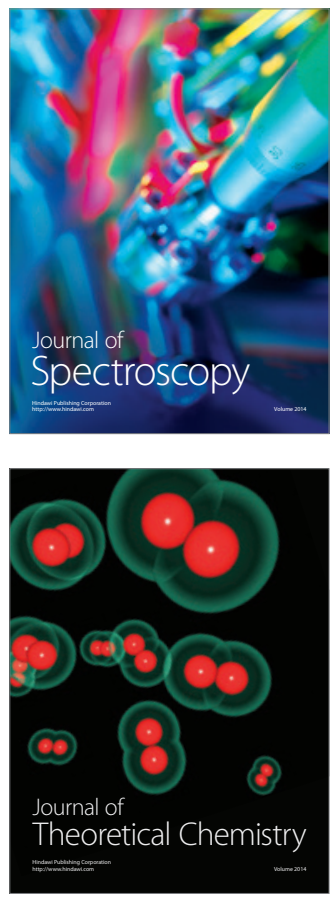
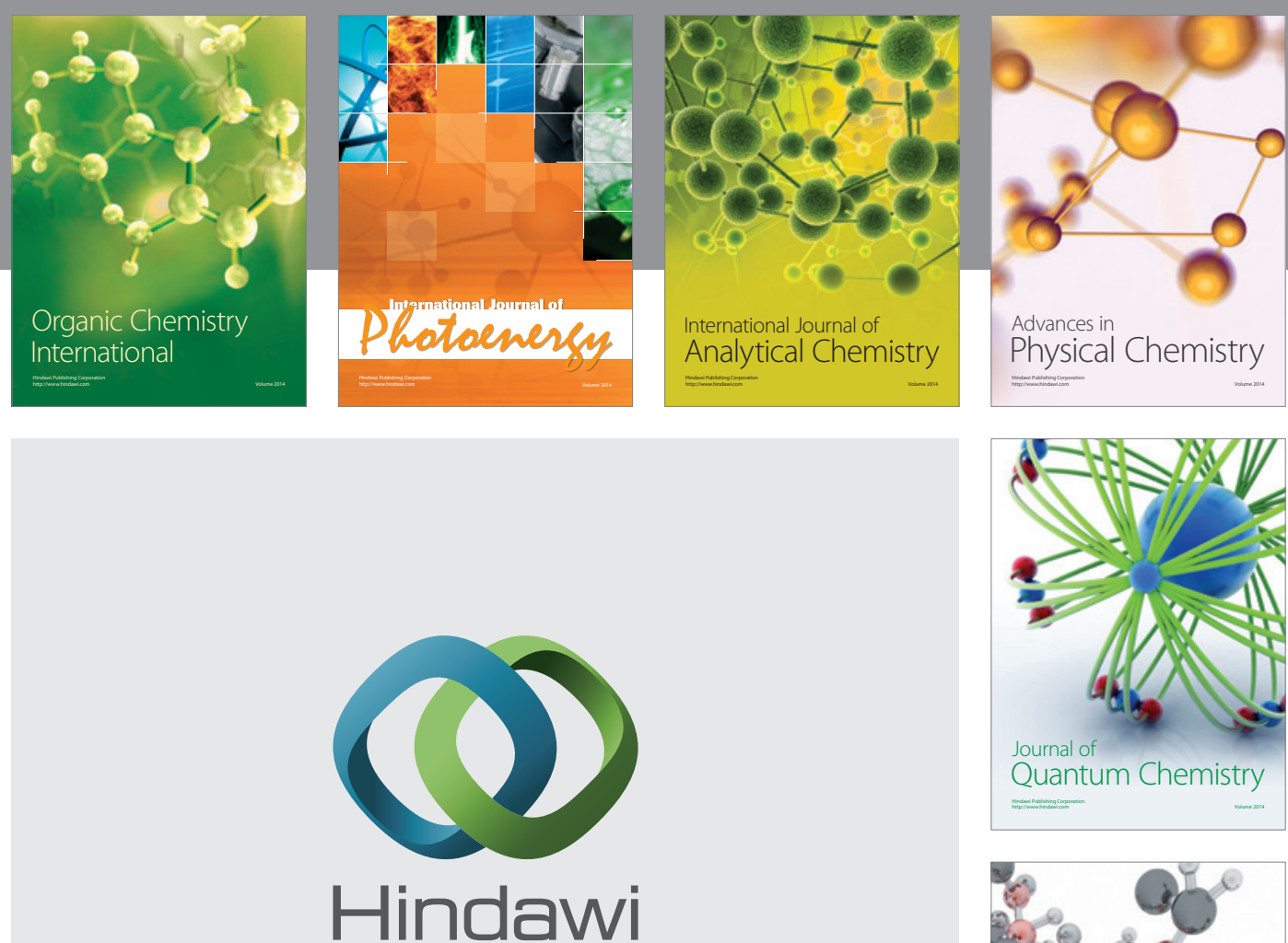

Submit your manuscripts at

http://www.hindawi.com

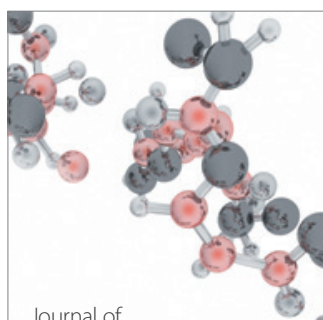

Analytical Methods

in Chemistry

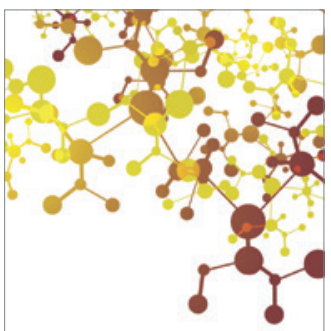

Journal of

Applied Chemistry

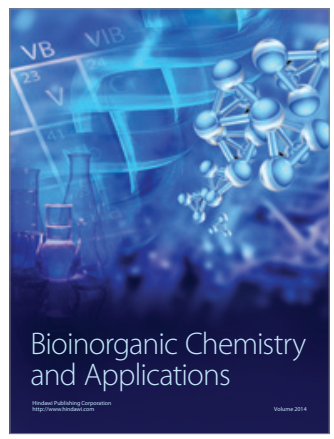

Inorganic Chemistry
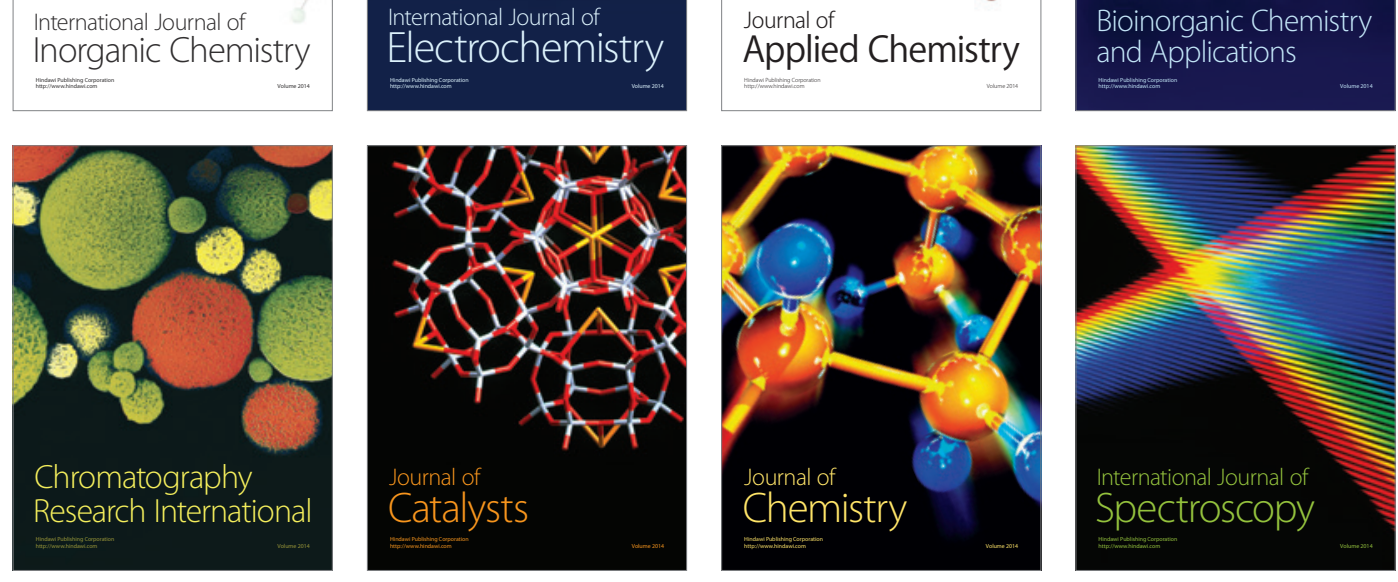